\title{
Impact of Density on Highest and Best Use of Residential Lands in Metropolitan Lagos
}

\author{
Adebayo, Michael Adedayo PhD. \\ Department of Estate Management, Federal University of Technology, Akure \\ Email: dayoadebayo2006@yahoo.com \\ Ogunleye, Mukaila Bamidele PhD.
}

Department of Estate Management, Federal University of Technology, Akure

Doi:10.5901/mjss.2014.v5n27p1698

\begin{abstract}
The aim of this study is to examine the impact of density on the highest and best use (HBU) of residential estate lands in metropolitan Lagos. The lists of estates (sampling frame) was arranged into three strata of low, medium, and high density of which one estate is purposively chosen from each stratum. The sampled estates are Ikeja GRA (low density), Ajao Estate, Isolo (medium density), and Oyadiran Estate, Yaba (high density). A total of 808 questionnaires were administered on the landlords but 542 were returned and used for the study. The data collected were analysed with the Multiple Linear Regression Analysis and Analysis of Variance - ANOVA. The study showed that the factors determining HBU in low, medium, and high density estates are different but the strongest factor common to all is accommodation units. It is therefore, recommended that residential land developers should take note of the difference in the determining factors so as to achieve the highest and best use of their land resource.
\end{abstract}

Keywords: Residential density, highest and best use, housing estate, Lagos metropolis.

\section{Introduction}

Density is generally defined as the amount of residential development permitted on a given parcel of land (USA-LGC, 2003). It is typically measured in dwelling units per acre - the larger the number of units permitted per acre, the higher the density; the fewer units permitted, the lower the density. Urban land use density is a measurement of the ratio of the intensity of use of land- use features for a geographic area. It may include the measure of the intensity of dwellings, structures or ground surface cover. Forsyth (2003) defines density as a number of units -people, dwellings, trees, square feet of buildings in a given land area and it varies greatly depending on the base land area used in the density calculation.. Obateru (2005) refers to density as the number of persons or object per unit of space such as the number of persons or houses per acre or hectare. In its simplest form, residential density can be described as some numerical measures of the extent to which land is occupied by buildings or people (Evans, 1973).

Residential densities are expressed in terms of dwelling units per hectare or in terms of bed spaces per unit, that is, in terms of the population expected to live on the site. Within a given city, permitted densities are likely to be higher in the inner areas than in the suburbs. For example, Lagos Island exhibited a higher residential land use density compared to any other residential areas of the metropolis

Some people have a negative attitude about high residential density. The belief is that high density is harmful to individuals and societies and that consumers always prefer low density development patterns (Moretti, 1999). However, many consumers value high density if it is well designed, affordable, increases accessibility and incorporates other valued amenities such as personal security and good schools.

The type of density concerned with in this study is housing density i. e. the number of houses per hectare. In this regard, three levels of density have been identified among the residential estates in Lagos. These are low density residential estates with an average plot size of 2000 square meters, medium density estates with average plot size of 750 square meters and high density estates with average plot size of 460 square meters. It is the aim of this study to examine the impacts of these various densities on the highest and best use of residential lands in Lagos metropolis. 


\section{Review of Related Literature}

Higher density development expands transportation choices by making it easier to use non-automobile transportation walking and bicycling by locating activities closer together. Studies indicate that the average resident in a compact neighborhood will drive to 20 to 30 percent less than residents of a neighborhood half as dense (LGC, 2003). High density has also been found to cut infrastructure costs. A report by the U.S office of technology assessment (OTA) found that it cost a western city ten thousand dollars more to provide infrastructure to a lower density sub urban development than to a more compact urban neighborhood.

Residential density is an indicator that low intensively land is being used to provide housing. Decker (2009) arguing for high residential density posits that it creates a range of housing choices for people of different incomes, ages, and household characteristics; support efficient delivery of transit service and preserve open space, agricultural land and natural systems by using land efficiently.

Low-density urban sprawl is identified by some as being a symptom of unsustainable urban development (Newman and Kenworthy, 1989; Rees, 1995; Newman, 1999) and various solutions aimed at achieving a more compact urban form has been prescribed, including polices of urban consolidation, urban containment and urban densification. On the other hand, Trainer(2001) has adopted the converse view that promotes low housing densities from a sustainable development perspective and holds that sustainable settlement must achieve huge reduction in resource use and environmental impact through increased self- sufficiency, and this requires space and relatively low housing densities. Others argue that there is little to be gained from higher urban densities. Braby (1989) argues that there are policies other than increasing urban densities which can overcome 'problems of inefficiency, ugly, noisy, polluted and environmentally destructive ' and which do not necessarily require a sacrifice of the leisurely living that goes with more open space and individualized transport. Mcloughlin (1991) also argues that increased residential densities save insignificant amount of land and they do so at what may be considerable social, economic, and environmental cost. Others still, suggest that we need to think beyond simply advocating higher densities as a panacea for sprawl and recognize the significance and complex interaction of many other processes within the urban system and focus our planning and development interactions accordingly.(Beekhout, 1992; Gollner, 1996 Ewing, 1997; Gordon and Richardson, 1997; Pund, 2001).

Density has many socio-economic effects on urban structure and fabric. From economic point of view, there is a direct relation between macro economy and investment in housing sector (Azizi, 2005). In general, development at a higher density may have economic efficiencies. These effects can be examined in the housing, land and infrastructure prices and costs. (Azizi, 2005) examined the challenges of urban development and density in Tehran and argued that by increasing density, land would be used and infrastructure would be provided efficiently. Moreover, the per capita cost of land per dwelling will tend to decrease as the density is increased, based on the economies of scale in the use of materials and other resources. The author however argues further that if density is increased disorderly and unplanned, its negative effects would be alarming. The costs of services such as provision of roads, water, drainage and sewerage lines tend to decrease with more compact development but once density is increased beyond a certain level, the cost of development begins to rise sharply. Therefore, an optimum density should be considered resulting in savings in the cost of development.

LSE (2006) summarizing issues raised in a debate about the best way to house a growing population in London supported the idea that planning densities should be increased, that higher densities will promote economic dynamism, reduce social segregation/exclusion and significantly reduce environmental cost notably carbon omissions from car usage by encouraging residents to make shorter trips.

The economics of urban residential density is also provided by Norman, MacLean and Kennedy (2006). The study provides an empirical assessment of energy use and green house gas omissions associated with high and low residential development using two case studies from the city of Toronto. Three major elements of urban development are considered: construction materials for infrastructure including residential dwellings, building operations and transportation. An economic input - output life-cycle assessment (E10 - LCA) model is applied to estimate the energy use and green house gas emissions associated with the manufacture of construction materials for infrastructure. The results show that low- density suburban development is more energy and green house gas intensive (by a factor of $2.0-2.5$ ) than high density urban core development on a per capital basis. When the functional unit is changed to per unit of living space basis, the factor decreases to $1.0-1.5$, illustrating that the choice of functional unit is highly relevant to a full understanding of urban density effects.

Roberts (2007) explores changes in urban density and its effects on the sustainability of urban development, functionality and management of Australian cities. The work is confined to an exploration of urban density demographic and urban residential development. The study adopts simple time series measurements of change in urban density for 
selected Australian cities drawing upon Australian Bureau of statistics - ABS and Satellite imagery data. The result shows that since 1990 the urban areas of Australia's largest cities (Sydney) are growing at over 2.4\% per annum while the population growth rate is around $1.2 \%$. The paper concludes that if these trends continue, the implications on the sustainability and development of Australian cities could be significant. This work has examined the implications of urban residential development and population density on sustainability but fails to explore the effect of urban density on the economic viability of various residential developments. This work will attempt to fill this gap.

Holden and Cijerde (2009) discusses the potential of improving the sustainability of existing cities and towns through residential use of roof-top additions to building in order to achieve sustainable higher density residential development. A hypothetical case study is presented wherein building on top is compared with demolishing the existing building and building a new. Variables such as life-cycle assessment, building materials, technology, reduction/avoidance of demolition waste, infrastructure and city services are considered for sustainability and economic performance. The paper concludes that building top apartments contribute to city sustainability and also contribute to better economic performance of higher density residential development.

In another empirical research work Bramley, Dunse, Thanas and Watkins (2009) examines the issues of housing type mix and density from the viewpoint of the key housing policy goal of 'affordability' and the key planning goal of sustainability, while also considering the essential practical requirement of economic viability. Building on hedonic price models and models of development costs, the different patterns of price/value and cost and the resulting viability calculation are mapped across a selection of city - regions in England using a range of model housing schemes involving different mix and density. The results show that the property market in England was quite capable of promoting high density apartment schemes and often apparently more affordable. Also, medium density, mixed schemes appear to optimize affordability. In the case of low-density development, the study shows that low-density detached houses look unaffordable. The hedonic price models however clearly shows that higher density and flat living are negatively evaluated by consumers, implying some loss from relying heavily on this form of provision.

\subsection{Concept of Highest And Best Use}

The concept of "highest and best use" is one of the most important and least understood principles in real estate. The highest and best use of a property, more than anything else, is what determines its value. The Appraisal Institute (2001) provides a definition of "Highest and Best Use" as the reasonably probable and legal use of vacant land or an improved property that is physically possible, legally permissible, appropriately supported, financially feasible and that results in the highest value.

According to Boddy (2002), highest and best use is defined as that use from among reasonably probable and adequately supported alternative uses which is legally permissible, physically possible, financially feasible and maximally productive. Black's Law (2004) defines 'Highest and best use' as the use that will generate the most profit. This standard is used especially to determine the fair market value of the subject to eminent domain.

Although, the definitions of 'Highest and Best Use' from the Appraisal Institute and Black's Law are somewhat similar, the Appraisal Institute's definition more accurately reflects the meaning and intent of 'Highest and Best Use' in the market. Underlying the definition and meaning of highest and best use are four implicit criteria that a property must meet. The Highest and best use must be physically possible considering the size, shape, terrain, accessibility, frontage, depth, utility capacity and availability; legally permissible with recourse to land use regulation; financially feasible calling attention to supply and demand, construction cost versus income/return benefit; and maximally productive in relative to other comparable alternatives.

\section{The Study Area}

Metropolitan Lagos is located within Lagos State in the south-western part of Nigeria. Although, there is no existing universally accepted definition of what constitutes Metropolitan Lagos, the Master Plan Unit of the Ministry of Economic Planning and Land Matters once defined it as "the area stretching from Lagos Island in the south to Agege and Isheri in the north, Ojo town in the west and Ikorodu town in the east". It is located approximately on latitude $6^{\circ} 22^{\prime} \mathrm{N}$ and $6^{\circ} 52 \mathrm{~N}$ and longitude $2^{\circ} 42^{\prime} E$ and $3^{\circ} 22^{\prime} E$ (Odumosu, 1999).

Metropolitan Lagos consists of 16 urban local governments out of the 20 local government areas in Lagos State (World Bank, 2005; FGN, 2007). They are Apapa, Ajeromi-Ifelodun, Alimoso, Agege, Amuwo-Odofin, Etiosa, Ifako-ljaiye, Ikeja, Kosofe, Lagos Island, Lagos Mainland, Mushin, Ojo, Somolu and Surulere. Lagos population according to the National Population Commission (2006) is 9.2 million. This figure is, however, being disputed by the Lagos State 
Government which claimed to have recorded a figure of about 18 million from a parallel census enumeration carried out.

Metropolitan Lagos comprises of heterogeneous population, with people belonging to diverse ethnic groups and nationalities. Lagos until 1991 was the capital of the Federal Republic of Nigeria. In spite of losing its position to Abuja as the Federal Capital, Lagos remains the commercial centre of the nation. Today, Lagos exerts influential and central role in Nigeria in spite of its small land area. Lagos State with only 0.4 percent of the nation's land area has about 7 percent of the nation's population. A field survey conducted in 2001 showed that undeveloped land in Lagos metropolis amounted to less than 30 percent (Babade, 2003). Now more than ever, one can clearly see the unprecedented lateral expansion of Lagos veering alarmingly out of control. The pace of development has now pushed the boundaries of urban Lagos beyond the boarders of Lagos State well into neighbouring Ogun State. Residential areas occupy the single largest proportion of 8,939 hectares (51.9\% of land area), (Oduwaye \&Dekolo, 2007). Residential estates of low, medium and high densities are identified in the metropolis (Oduwaye, 2001).

\section{Research Method}

The design adopted for this study is descriptive while the sampling methods are purposive and stratified. The list of estates (sampling frame) is arranged into three strata of low, medium and high densities. In order to include some important estates, one residential estate is chosen from each stratum using purposive sampling method. The purposive sampling method helps to choose the estates that adequately represent all the estates in each stratum. In this wise, the following estates are chosen: Ikeja GRA, (low density); Ajao Estate-Isolo, (medium density); and Oyadiran Estate (high density). These estates are chosen due to their unique characteristics in terms of density, geographical location and ownership. The sample size from each of the estates has been determined statistically using Yamane (1967) model of estimating an appropriate sample size of a finite population. A total of 808 questionnaires were administered on the landlords in the studied estates while 542 were returned and found useful for analysis. The study considers the following variables namely: annual rental value, building type, accommodation units, zoning regulation, land cost, plot size, accessibility, building cost, market competition and demand. These variables are identified through review of related literature and the concepts of highest and best use of lands as vacant or developed. The Multiple Linear Regression Analysis is used to determine the contribution of each of the variables to the HBU of residential lands as developed while Analysis of Variance-ANOVA is employed to test the study hypothesis posited.

\section{Results and Discussion}

The results of the regression analyses of significant variables determining HBU in the three studied estates are combined in Table 1 for easy comparison.

Table 1: Comparative Analysis of Significant Variables Determining HBU in Residential Estates in Lagos

\begin{tabular}{|c|c|c|c|c|c|c|c|c|}
\hline \multirow[b]{2}{*}{ Constant } & \multicolumn{2}{|c|}{$\begin{array}{c}\text { Low Density } \\
\text { B Sig }\end{array}$} & \multicolumn{2}{|c|}{$\begin{array}{c}\text { Medium Density } \\
\text { B Sig }\end{array}$} & \multicolumn{2}{|c|}{$\begin{array}{c}\text { High Density } \\
\text { B Sig }\end{array}$} & \multicolumn{2}{|c|}{$\begin{array}{l}\text { Combined } \\
\text { B Sig }\end{array}$} \\
\hline & 2.492 & .104 & .254 & .653 & -.470 & .753 & -2.264 & .000 \\
\hline Building Type & $-.845^{\star \star}$ & .000 & .018 & .701 & -.017 & .888 & .068 & .370 \\
\hline Accommodation & $.793^{\star *}$ & .000 & $.124^{\star *}$ & .000 & $.183^{\star \star}$ & .000 & $.218 * *$ & .000 \\
\hline Zoning Regulation & -.065 & .900 & -.060 & .753 & -.140 & .645 & .075 & .777 \\
\hline Land cost & .010 & .442 & $-.088^{* \star}$ & .001 & $.086^{*}$ & .038 & $.032 * \star$ & .005 \\
\hline Plot size & .000 & .558 & $.002^{*}$ & .011 & .000 & .820 & $.002^{* *}$ & .000 \\
\hline Accessibility & -.361 & .182 & -.036 & .787 & -.341 & .154 & -.230 & .193 \\
\hline Building cost & .004 & .768 & $.060 * *$ & .000 & .021 & .295 & .010 & .364 \\
\hline Demand & -.181 & .486 & .135 & .216 & .097 & .675 & $.490 * *$ & .002 \\
\hline Market competition & .747 & .078 & -.047 & .539 & .095 & .646 & -.182 & .202 \\
\hline Df & 9 & & 9 & & 9 & & 9 & \\
\hline F-value & $84.541^{\star \star}$ & .000 & $55.448^{\star *}$ & .000 & 13.890 ** & .000 & $209.099 \star *$ & .000 \\
\hline $\mathrm{R}^{2}$ & -840 & & .696 & & .456 & & .780 & \\
\hline
\end{tabular}

Source: Analysis of Survey, 2012 * Significant at 0.05 level ** Significant at 0.01

Table 1 presents the comparative analysis of significant variables determining HBU in low, medium and high density 
estates in Lagos. The analysis of the combined data from all the densities is also presented on the table. The significant variables determining HBU in low density estates are building type and accommodation, that of medium density are accommodation, land cost, plot size and building cost, high density estates determinant variables are accommodation and land cost.

\section{Testing Of Hypothesis}

The study set a hypothesis to give direction to validate or otherwise those factors determine the highest and best use of residential lands in low, medium and high density residential estates in Lagos. The hypothesis is stated thus:

$\mathrm{H}_{01}$ : There is no significant difference in the factors that determine highest and best use of residential lands in Lagos.

Mathematically stated thus:

$\mathrm{H}_{0}=\mathrm{HBU}_{\mathrm{L}}=\mathrm{HBU}_{M}=\mathrm{HBU}_{\mathrm{H}}$

Where

$\mathrm{HBU}=$ = Factors determining highest and best use in low density estates

$\mathrm{HBU}_{\mathrm{M}}=$ Factors determining highest and best use in medium density estates

$\mathrm{HBU}_{\mathrm{H}}=$ Factors determining highest and best use in high density estates

The Analysis of Variance (ANOVA) is employed to test the hypothesis. The result is presented on Table 2.

Table 2: Analysis of Variance of Factors Determining HBU of Residential Lands in Lagos

\begin{tabular}{lccccc}
\hline Model & Sum of squares & Df & Mean square & F & Sig. \\
\hline Regression & 5541.649 & 9 & 615.739 & 209.099 & .000 \\
Residual & 1566.594 & 532 & 2.945 & & \\
Total & 7108.243 & 541 & & & \\
\hline
\end{tabular}

Source: Computer output on survey data, 2012.

Table 2 shows the analysis of variance of factors determining highest and best use of residential lands in Lagos. The level of significance attached to $F$-value $(F=209.099)$ in the ANOVA is 0.000 . At $5 \%$ level, the level of significance in the ANOVA $(0.000)$ is less than 0.05 . Hence, the null hypothesis which states that there is no significant difference in the factors that determine highest and best use of residential lands in Lagos will be rejected. The alternative hypothesis that says that there is significant difference in the factors that determine HBU of residential lands in Lagos shall be accepted. This assertion is based on cogent reasons of social and economic conditions of people purchasing and developing properties in the different densities. The high income group, the middle income and the low income groups occupy the low density, medium and high density residential lands respectively. Even though, every level of occupier considers the units of accommodation in a property to determine the price to pay for such property, a high income earner would consider the type of building and ample space (both internal and external) to determine what to offer to purchase a property in the low density area. On the other hand, a low income earner investor in the high density area would consider the cost of land purchased and how to maximize its use to the fullest. If permitted by law, such developer is ready to develop every each of his plots of land. In the medium density, a property developer would also want to consider the cost of the land, the building cost and even the plot size that will dictate the type of property his target prospective customers can willingly pay for in the open market.

\section{Conclusions and Recommendation}

The two major factors to be considered by property investors in low density estates to achieve maximum productivity $(\mathrm{HBU})$ are accommodation units and the building type. The higher the number of accommodation units, the higher the rental and capital values.

In medium density estates, to achieve the highest and best use of lands, accommodation, land cost, plot size and building cost must be considered. Property investors in high estates are to consider the factors of accommodation and land cost so as to achieve the maximum productivity. The factors that determine highest and best use of land in low, medium and high density estates are different but the strongest factor common to all is accommodation. It is therefore, recommended that residential land developers should take note of the different determining factors of HBU in the various 
densities in Lagos metropolis.

\section{References}

Aziz Mohammed M. (2005). The challenges of Urban Development and Density in Tehvan. Paper presented at International Conference for Integrating Urban Knowledge and Practice. Gothenburg, Sweden, May 29 - June 3.

Babade, T. (2003). Access to Urban Land in Nigeria: An Analysis of the Activities of Lagos State Land Use and Allocation Committee in Omirin et al. eds. Land Management and Property Tax Reform in Nigeria. Proceedings of a National Workshop organized by the Department of Estate Management, University of Lagos, Nigeria.

Barmley G, Dunse N, Thomas S., and Watkins D. (2009). The Role of Mix, Density and Location of new Housing in Achieving Sustainability and Affordability. Paper presented at ENHR European Housing Research Conference, Prague, June.

Beekhout, V. (1992). "Urban Consolidation", Australian Planner 30(1): 20-24

Boddy, C. (2002) "Highest and Best Use. Back to the Land Mendocino Coast Real Estate Magazine. Htt;://www.chetboddy.com/ highestbest.html

Braby, R. (1989) "Determinants of Density", Urban Policy and Research 7(4): 147-156.

Decker, S. (2009) Suburban Low Medium High Residential Density. The City of Calgary Land Use Planning and Policy. Calgary.ca/geodemographics.

Evans, P. (1973) "Housing Layout and Density", University of Cambridge, Department of Architecture, Land Use and Built Form Studies, Working Paper No.75, Cambridge.

Ewing, R. (1997) "Is Los Angeles-style Sprawl desirable?", Journal of American Planning Association 63(1): 107-126.

Federal Republic of Nigeria Official Gazette (2007): Legal Notice on Publication of the Details of the Breakdown of the National and State Provisional Total, 2006 Census (PDF), Retrieved on 2008-10-29.

Forsyth, A (2003) "Measuring Density: Working Definitions for Residential Density and Building Intensity". Design Center for American Urban Landscape, Design Brief No.8, July.

Gollner, A. (1996) "To Sprawl or Not to Sprawl?", Australian Planner 33(3): 136-141.

Gordon, P. and Richardson, H. W. (1997) "Are Compact Cities a Desirable Planning Goal?" Journal of the American Planning Association 63 (1): 95 - 106.

Holden and Gjerde (2009). Sustainable Higher Density Residential Development. Paper presented at $2^{\text {nd }}$ International Urban Design Conference, Gold Coast. September.

Local Government Commission (2003) "Creating Great Neighborhoods: Density in your community". National Association of Realtors, Washington D.C.

Moretti, F.R. (1999) Smart Growth: A Wolf in Sheep's Clothing? The Road Information Program (www.tripnet.org/smartgrowth.htm).

Neuman, M. (1999) The Compact City Fallacy and Beyond: Planning Sustainable Urban Development. College of Architecture, Texas A \& M University.

Newman, P. (1999) "Sustainability and Australian Cities", Australian Planner 36(2): 93-100.

Newman, P. and Kenworthy, J. (1989) Cities and Automobile Dependence: an International Source Book. Gower Publishing Ltd, Aldershot.

Norman, J. Maclean, H. S and Kennedy, C. A. (2006). Comparing High and Low Residential Density: Life-cycle Analysis of Energy Use and GreenHouse Gas Emissions. Journal of Urban Planning and Development (132(1), 10 - 21.

Obateru, O.I. (2005) Controlling Residential Densities. Penthouse publications (Nig.), Ibadan.

Oduwaiye L. and Dekolo S. O. (2007). Land Values in Low Density Residential Neighbourhoods of Metropolitan Lagos. Journal of Geography, Environment and Planning, 3(2), 50-68.

Oduwaiye, A. O. (2001). Residential Land Use and Land Values in Metropolitan Lagos. Unpublished Ph.D. thesis, Urban and Regional Planning Dept. Obafemi Awolowo University, lle-Ife.

Pund, G. (2001) "City Density and Public Transport", Australian Planner 38(2)" 74-79.

Rees, W. (1995) "Achieving Sustainability: Reform or Transform?", Journal of Planning Literature 9(4): 343-361.

Robert B. H. (2007). Changes in Urban Density: Its implications on the sustainable Development of Australian Cities. Paper presented at the State of Australian Cities National Conference.

Trainer, T. (2001) "Radical Implications of the Limits to Growth Analysis", Australian Planner 38(2): 90-95.

Yamane T. (1967) Statistics: An Introductory Analysis, $2^{\text {nd }}$ ed., Harper and Row, New York. 